\title{
Art Music by Caribbean Composers: Bonaire
}

\section{Christine Gangelhoff \\ The College of The Bahamas ${ }^{1}$ \\ Cathleen LeGrand \\ Royal Thimphu College, Bhutan}

\section{INTRODUCTION}

Bonaire is the most easterly of the "ABC" (Aruba, Bonaire, Curaçao) islands of the former Netherlands Antilles ("Bonaire island", 2013). After a period of Spanish rule, Bonaire has been under Dutch control since 1636 (Bilby, 2013). As of 2010, the island has been a special municipality of the Kingdom of the Netherlands ("Bonaire", 2012). Situated only 50 miles north of Venezuela and its oil industry, oil transhipment forms part of the island's economy ("Bonaire island", 2013).

The island is formed of limestone and has an arid climate, qualities making it less suitable for the agricultural plantations that were common on other Caribbean islands. The island's salt flats were more easily exploited and salt production has long been one of Bonaire's major industries ("Bonaire", 2012).

The island is surrounded by coral reef, making it a popular destination among divers who help make tourism a growing industry in Bonaire ("Bonaire island", 2013). Bonaire served as a slave market before the abolition and much of the island's current population is descended from slaves ("Bonaire", 2012).

Bonaire has musical traditions similar to those of its Antillean neighbors, Aruba and Curacao. All three islands "share a neoAfrican, drum-centred tradition known as tambu (in Bonaire often referred to as bari), a quintessential Netherlands Antilles folk music" (Bilby, 2013, para. 4). Tumba, a unique mixture of tambu music with other, more modern musical elements, is a particularly popular local musical style (Bilby, 2012).

Music in Bonaire has been strongly influenced by its neighbours to the south, Venezuela and Colombia. The influence of European ballroom dances, such as the schottishe, the mazurka and the quadrille can also be felt. 'Both 'purer' and more creolized versions of these [dances] have long formed part of the repertories of dance bands" on Bonaire and the other Lesser Antilles (Bilby, 2012, para. 9).

\footnotetext{
${ }^{1}$ Christine Gangelhoff, Assistant Professor, School of Communication and Creative Arts, The College of The Bahamas, P.O. Box N-4912, Nassau, Bahamas; Cathleen LeGrand, Librarian, Royal Thimphu College, Ngabiphu, Thimphu, Bhutan.

Acknowledgments: The authors would like to thank Johannes "Joop" Halman, Hans Odin Faassen and Livio Hermans for their contributions to and assistance with this chapter.

E-mail: cgangelhoff@cob.edu.bs

APA reference: Gangelhoff, C., \& LeGrand, C. (2013). Art music by Caribbean composers: Bonaire. The International Journal of Bahamian Studies, 19(2), 17-18. https://doi.org/10.15362/ijbs.v19i2.202
} 
West African influences are also visible in the musical and cultural traditions of Bonaire. Songs and dances surviving from the time of slavery and intermingled with New World styles can be seen in the music of Simadan, a harvest festival (Razak, 2005).

The Classical Music Board Bonaire, established in 2009, works to "promote, organize and develop classical concerts on Bonaire" for both residents and tourists ("Classical Music Board", 2013). The Classical Music Board Bonaire is especially interested in creating opportunities for the performance of local Antillean classical music.

\section{REFERENCES}

Bilby, K. (2013). Netherlands Antilles and Aruba. In Grove music online. New York, NY: Oxford University Press.

Bonaire. (2012). In Britannica concise encyclopedia. Retrieved from http://0www.credoreference.com.helin.uri.edu/ent ry/ebconcise/bonaire

Bonaire island. (2013). In The Hutchinson encyclopedia. Retrieved from http://0www.credoreference.com.helin.uri.edu/ent ry/heliconhe/bonaire_island
Classical Music Board of Bonaire. (2013).

Retrieved from

http://classicalmusicbonaire.com/foundatio $\mathrm{n} / \mathrm{cmbb} . \mathrm{html}$

Razak, V. M. (2005). Netherlands Antilles. In Continuum encyclopedia of popular music of the world: Locations. Retrieved from http://0www.credoreference.com.helin.uri.edu/ent ry/contpmwl/netherlands_antilles

\section{COMPOSERS}

Domenico B. Herrera

COMPOSITIONS, by composer

\section{Herrera}

Atardecer en Curazao

Bonaire

Dominguin

Elina

Feddy

Jeanette Amelia

\section{Joan}

Maritza

Mi a scapa

Noche de fiesta

Tan chita

Te saludo Aruba

\section{LIBRARIES \& OTHER ORGANIZATIONS}

Classical Music Board Bonaire http://www.classicalmusicbonaire.com/inde x.html 